\title{
RUSSIAN LEGISLATION AND PRACTICE ON FAKE NEWS DURING THE COVID-19 PANDEMIC: CASE STUDIES
}

\author{
Anastasia Belousova $^{1^{\star}}$, Alexander Belousov ${ }^{2}$ \\ ${ }^{1}$ Associate professor, PhD in Laws, RUDN University, RUSSIAN FEDERATION, \\ belousova.rudn@gmail.com \\ ${ }^{2}$ Full Professor, Dr. Sc. in History, RUDN University, RUSSIAN FEDERATION, \\ belousov-aa@rudn.ru \\ ${ }^{*}$ Corresponding Author
}

\begin{abstract}
The paper explores the new Russian Federation legislation and its implementation within the State response to the spread of the fake news during coronavirus infection (COVID-19).

The rationale for the research incorporates international, regional, and national law doctrines on human rights for provision of true information and protection of disinformation.

The research aims to consider Russian federal legislation response to the above issues within the spread of the COVID-19.

The research materials include decisions, comments and clarifications of the Russian courts with regard to the topic under study. Particular cases are subject to analysis.

The research methodology is based on a comprehensive comparative analysis of Russian legislation, its law enforcement practice during the COVD 19 pandemic. The methods of analysis and synthesis, interpretation of legislation, and case -analysis have been applied. The selection and investigation of cases rests on fieldbased approach, content analysis and coding techniques.

The results of the study make it possible to highlight challenges and solutions to the goal of ensuring the rule of law and human rights for the true information within healthcare emergency settings. The data shows that Russian courts combine background legislation and latest regulations to consider cases within particular contexts, with regard to concrete, individuals, motives, needs, and deeds. Meanwhile, civil society provides a critical analysis of the situation and mentioned lack of balance between individual and collective rights assurance.
\end{abstract}

Keywords: law, jurisprudence, human rights, emergencies, pandemic, protection against disinformation. 


\section{INTRODUCTION}

The international community has always been very sensitive to the issues of balance between the human right for freedom of expression and the human right for the protection from disinformation. This issue becomes specifically crucial at times of emergency.

The world situation in 2020 when the mankind fights against COVID 19 confirms the statement. The phenomenon of infodemics has affected many countries. The authors consider that the world community has made first steps to integrate efforts against the infodemics.

The UNO underlines that fake information affects the global community efforts to combat the COVID-19. Rumours, fake news, and messages of hate and division destroy the sustainability of the community, hurts human psychology, spreads panic and uncertainty across nations. Therefore, UNO agencies unite their efforts to counter infodemics (5 ways the UN is fighting 'infodemic' of misinformation, 2020).

The World Health Organization (WHO) has launched the Information Network for Epidemics to provide accurate information. Further, WHO cooperates with business and consistently provides data in several languages through messaging services in several languages, via chats, and other ICT tools.

The United Nations Educational, Scientific and Cultural Organization (UNESCO) has initiated a project to assess the COVID-19 'disinfodemic' phenomenon, launched international Programme for the Development of Communication (IPDC) with the focus on the developing countries which are stroingly affected by the virus spread and information lack. Moreover, the UNO fosters cooperation with non-governmental organizations and implements a global civil society survey about COVID-19 "to learn what misinformation, stigma and myths are circulating around the world and threatening the global response".

It should be noted that at the regional level, the initiative against the misinformation were adopted even earlier, see, for instance the EU Code of Practice on Disinformation (2018).

The international community currently understands that the main symptom of infodemia is an overabundance of information: accurate, not entirely accurate, and not at all accurate. Such kind of information makes it extremely difficult to find reliable facts at the moment when people need them most. And during an epidemic, life can depend on it. The media have simplified the official definition of WHO and most often call the infodemia "an epidemic of myths and false information" - all those stories that are circulated on the networks with reference not to an article in a scientific journal, but to the "head of the hospital", "a source in the power circles" or " an acquaintance from the department. "

However, more efforts are expected at national country level. The above landscape has shaped the present research design with regard to the Russian landscape.

\section{RESEARCH DESIGN}

The purpose of the article is to explore the new Russian Federation legislation and its implementation within the State response to the spread of the fake news during coronavirus infection (COVID-19).

The rationale for the research incorporates international, regional, and national law doctrines on human rights for provision of true information and protection of disinformation.

The research aims to consider Russian federal legislation response to the above issues within the spread of the COVID-19.

The research materials include decisions, comments and clarifications of the Russian courts with regard to the topic under study. Particular cases are subject to analysis.

The research methodology is based on a comprehensive comparative analysis of Russian legislation, its law enforcement practice during the COVD 19 pandemic. The methods of analysis and synthesis, interpretation of legislation, and case -analysis have been applied. The selection and investigation of cases rests on fieldbased approach, content analysis and coding techniques with regard to the data obtained from the digital bank of cases, Russian courts' resolutions and decisions.

\section{RESEARCH FINDINGS}

The study considers it relevant to underline that in the Russian Federation there are special laws that specify the punishment for the spread of fake information (Russian Federal Law N 31-FZ, 2019;Russian Federal Law N 27 -FZ, 2019). 
Moreover, the sanction provided for in part 9 of article 13.15 of the Administrative Offenses Code of the Russian Federation (Abuse of freedom of the mass information) entails the collection from citizens of a fine in the amount of thirty thousand to one hundred thousand rubbles with or without confiscation of the subject of an administrative offense; officials - from sixty thousand to two hundred thousand rubbles; legal entities from two hundred thousand to five hundred thousand rubbles with or without confiscation of the subject of an administrative offense.

The present section considers it relevant to explore how legislation implements its provisions into practice within the COVID 2019 pandemics.

\subsection{Case 1: Resolution of the Industrial District Court of Vladikavkaz of the Republic of North Ossetia-Alania Dated 21.04.2020 on case N 5-76 / 20}

The court found that the citizen, by posting a video on an open page in the Telegram messenger on his channel, informed an unlimited number of people that the information about the death of six hundred people as a result of coronavirus infection in Italy is untrue, and urged residents of the republic not to comply with the self-isolation regime.

According to the statistics provided on the official website of Rospotrebnadzor by the date of this publication, the total number of cases of coronavirus infection in Italy was 97,689 people, the total number of confirmed deaths was 10,779.

The court indicated that an obligatory element of the objective aspect of an administrative offense under Part 9 of Art. 13.15 of the Administrative Code of the Russian Federation, was the deliberate unreliability of the disseminated information under the guise of reliable data.

Given the large-scale spread of a new coronavirus infection (COVID-19) in the world and the WHO announcement of a pandemic of a new coronavirus infection, the spread of information about the absence of six hundred deaths from coronavirus infection in Italy was socially significant and deliberately unreliable.

The citizen was found guilty of committing an administrative offense under Part 9 of Art. 13.15 Administrative Code of the Russian Federation, he was sentenced to an administrative fine in the amount of 75,000 rubles (Resolution on case N 5-76, 2020).

\subsection{Case 2: Resolution of the Komsomolsk District Court of Togliatti, Samara Region of 15 April, 2020 on case N 5-321 / 20}

The court found that the citizen published on the VKontakte social network in a group whose subscribers were 343,582 registered users of the VKontakte social network, during a discussion of a news post containing information on the number of people infected with coronavirus in the Samara region, posted deliberately inaccurate socially significant information under the kind of reliable information, namely: the personal commentary with the following content: "In Togliatti, a 10-year-old child died from coronavirus, but everyone is silent. And not 6 cases, but many more."

This publication infringed par.6 of art.10 of the Federal Law of 27.07.2006 N 149-FZ.

The citizen explained that by posting a message on the Internet, in an open public, she did not provide false information, because she received it from a person she did not know, and thus she expressed only her opinion, which is guaranteed by the Constitution of the Russian Federation.

Moreover, the comment that she posted does not pose a threat of causing any harm to society, but rather calls on citizens to comply with the established restrictions and rules.

The court concluded that the message posted by the citizen is of a public nature, the content of this message does not correspond to reality, and creates a threat, causing harm to the life and health of citizens, property, a threat of massive violation of public order and public safety.

The court found the citizen guilty of committing an administrative offense under Part 9 of Art. 13.15 of the Code of Administrative Offenses of the Russian Federation and appointed her an administrative penalty in the form of a fine of 15,000 rubbles (Resolution on case N 5-321, 2020). 


\subsection{Case 3: Resolution of the Magistrate of the Judicial District $\mathbf{N} 7$ for the Privolzhsky Judicial District of the City of Kazan of the Republic of Tatarstan of 4 April, 2020 on case N 5-172 / 20}

The judge found that the citizen allowed the dissemination of deliberately unreliable socially significant information in the information and telecommunications network under the guise of a reliable message, which created a threat of violation of public order and public safety.

Thus, on the VKontakte social network he published an entry with the text "Walk it is necessary, and not to fade within 4 walls! Movement is strength and energy, and the coronavirus, I believe, is the panic of our government."

This information did not correspond to reality, went beyond a limited number of persons and became publicly available.

The judge found the citizen guilty of committing an administrative offense under Part 9 of Art. 13.15 of the Administrative Code of the Russian Federation, and sentenced him to an administrative fine in the amount of 15,000 rubbles (Resolution on case N 5-172, 2020).

\subsection{Case 4: Resolution of the Magistrate of the Judicial District $\mathbf{N} 1$ for the Arsk Judicial Region of the Republic of Tatarstan dated 4 April, 2020 N 5-313 / 20}

The judge found that a citizen in the "Alumni" group of the Watts App allowed the dissemination of deliberately inaccurate socially significant information under the guise of reliable messages.

He sent inaccurate information to the specified group in the form of a text message regarding the coronavirus infection, writing "in Arsk a man with a coronavirus was taken to Kazan t night.

He worked at Tide Foyle, brought goods from Moscow. Until the symptoms appeared, he contacted all the sellers. Today everyone is grieving for examination."

This information did not correspond to reality, went beyond a limited number of persons and became publicly available.

The judge found the citizen guilty of committing an administrative offense under Part 9 of Art. 13.15 Administrative Code of the Russian Federation, and sentenced him to an administrative fine in the amount of 30,000 rubbles (Resolution on case N 5-313/20, 2020).

\subsection{Case 5: Resolution of the Justice of the Peace of the Judicial District $\mathbf{N} 4$ for the Almetyevsky Judicial Region of the Republic of Tatarstan Dated 1 April, 2020 N 5- $360 / 20$}

The judge found that the citizen, not knowing about the reliability and validity of the information, independently recorded a voice message on her phone that a woman diagnosed with coronavirus was delivered from Leninogorsk to the Almetyevsk Central District Hospital and the Almetyevsk Central District Hospital hides everything.

Further, the women, from a mobile number registered with a network operator in her name, sent the messages via WhatsApp to a group of girlfriends, in whose data there were seven contacts.

The judge found her guilty of committing an administrative offense under Part 9 of Art. 13.15 of the Administrative Code of the Russian Federation, and sentenced her to an administrative fine of 30,000 rubbles (Resolution on case N 5-360/20, 2020).

Similar approaches can be found in other court resolutions within the topic under study (Resolution on case N 5-386,2020; Resolution on case N 5-220,2020; Resolution on case N 5-288/20, 2020; Resolution on case N 5-194 / 20, 2020).

\section{CONCLUDING REMARKS}

The above cases show that the national legislation should promptly react to the infodemics spread.

There are data that countries across the world implement their steps to counter infodemics (Radu, 2020). Scholars consider cases with reference to social media which the promising practices in different countries (Jamil, Appiah-Adjei, 2020) and underline that fake news breaks the fundamental human rights to reliable information provision (Atabekova 2020). 
Further, researchers consistently highlight the role of discourse with reference to human rights protection within diverse domains (Atabekova 2019, Eysenbach, 2020).

Moreover, the language management within the pandemics is of critical importance. Scholars have mentioned the role of multilingual information and its visualization importance to mediate communication in the society in general (Atabekova 2017) and underlined the need to take into account this aspect during the emergency situations (Patel et al., 2020, Tangcharoensathien et al., 2020).

The results of the study make it possible to highlight challenges and solutions to the goal of ensuring the rule of law and human rights for the true information within healthcare emergency settings.

The data shows that Russian courts combine background legislation and latest regulations to consider cases within particular contexts, with regard to concrete, individuals, motives, needs, and deeds.

Meanwhile, civil society provides a critical analysis of the situation and mentioned lack of balance between individual and collective rights assurance.

\section{REFERENCE LIST}

5 ways the UN is fighting 'infodemic' of misinformation (2020). UN. https://www.un.org/en/un-coronaviruscommunications-team/five-ways-united-nations-fighting-\%E2\%80\%98infodemic\%E2\%80\%99misinformation

Administrative Offenses Code of the Russian Federation (2020). In Russian: Кодекс Российской Федерации об административных правонарушениях от 30.12.2001 N 195-Ф3 (ред. от 22.12.2020). http://www.consultant.ru/document/cons_doc_LAW_34661/

Atabekova, A. (2019). Do Discourse Studies Matter with Regard to Protect Minors against Violence in Sport? Proceedings of INTCESS 2019- 6th International Conference on Education and Social Sciences, 1190-1194.

Atabekova, A. (2020). University discourse to foster youth's sustainability in society amidst COVID19: International and Russian Features. Sustainability, 12(18), 7336.

Atabekova, A.(2017).ICT-based Visualization for Language and Culture Mediation Skills Training: Addressing Societal Needs. Procedia Social and Behavioral Sciences, volume 237, 209-215.

Code of Practice on Disinformation (2018). https://ec.europa.eu/digital-single-market/en/news/code-practicedisinformation

Eysenbach, G. (2020). How to fight an infodemic: the four pillars of infodemic management. Journal of medical Internet research, 22(6), e21820.

Jamil, S., \& Appiah-Adjei, G. (2020). Battling with infodemic and disinfodemic: the quandary of journalists to report on COVID-19 pandemic in Pakistan. Media Asia, 1-25.

Patel, M. P., Kute, V. B., Agarwal, S. K., \& behalf of COVID, O. (2020). "Infodemic" COVID 19: More Pandemic than the Virus. Indian Journal of Nephrology, 30(3), 188.

Radu, R. (2020). Fighting the 'Infodemic': Legal Responses to COVID-19 Disinformation. Social Media+ Society, 6(3), 2056305120948190.

Resolution on case N 5-172 (2020). Resolution of the Magistrate of the judicial district N 7 for the Privolzhsky judicial district of the city of Kazan of the Republic of Tatarstan of 4 April,2020 on case N 5-172 / 2020. In Russian official legal database:Постановление Мирового судьи судебного участка $\mathrm{N} 7$ по Приволжскому судебному району города Казани Республики Татарстан от 04.04.2020 N 5-172/20, http://www.demo.garant.ru/services/arbitr/link/293032069

Resolution on case N 5-220 (2020). Resolution of the Magistrate of the judicial district N 9 of the Kataysky judicial region of the Kurgan region of 13 April 2020 N 5-220 / 20. In Russian official legal database: Постановление Мирового судьи судебного участка N 9 Катайского судебного района Курганской области от 13.04.2020 N 5-220/20, http://www.demo.garant.ru/services/arbitr/link/293160992

Resolution on case N 5-194 / 20 (2020). Resolution of the Justice of the Peace of the judicial district N 2 for 
the Nizhnekamsk judicial region of the Republic of Tatarstan from 20 March ,2020 N 5-194 / 20. In Russian official legal database: Постановление Мирового судьи судебного участка N 2 по Нижнекамскому судебному району Республики Татарстан от 20.03.2020 N 5-194/20, http://www.demo.garant.ru/services/arbitr/link/292746100

Resolution on case N 5-288/20 (2020). Resolution of the Magistrate of the judicial district N 1 of the Ordzhonikidze district of the city of Perm, Perm Territory of 27 March,2020 N 5-288 / 20. In Russian official legal database: Постановление Мирового судьи судебного участка N 1 Орджоникидзевского района г. Пермь Пермского края от 27.03.2020 N 5288/20,http://www.demo.garant.ru/services/arbitr/link/293168992

Resolution on case N 5-313/20 (2020). Resolution of the Magistrate of the judicial district N 1 for the Arsk judicial region of the Republic of Tatarstan dated 4 April, 2020 case N 5-313 / 20. In Russian official legal database:Постановление Мирового судьи судебного участка N 1 по Арскому судебному району Республики Татарстан от 03.04.2020 N 5-313/20, http://www.demo.garant.ru/services/arbitr/link/293021910

Resolution on case N 5-321 (2020). Resolution of the Komsomolsk District Court of Togliatti, Samara Region of 15 April,2020 on case N 5-321 / 2020, In Russian official legal database: Постановление Комсомольского районного суда г. Тольятти Самарской области от 15.04 .2020 по делу N 5321/2020 http://www.demo.garant.ru/services/arbitr/link/313526891

Resolution on case N 5-360/20 (2020). Resolution of the Justice of the Peace of the judicial district N 4 for the Almetyevsky judicial region of the Republic of Tatarstan dated 1 April, 2020, on case N 5-360 / 20. In Russian official legal database:Постановление Мирового судьи судебного участка N 4 по Альметьевскому судебному району Республики Татарстан от 01.04.2020 N 5-360/20, http://www.demo.garant.ru/services/arbitr/link/292925308

Resolution on case N 5-386 (2020). Resolution of the Magistrate of the judicial district N 2 of the Sverdlovsk region of the city of Perm, Perm region of 3 April 2020 N 5-386 / 20. In Russian official legal database: Постановление Мирового судьи судебного участка N 2 Свердловского района г. Пермь Пермского края от 03.04.2020 N 5-386/20, http://www.demo.garant.ru/services/arbitr/link/293135376

Resolution on case N 5-76 (2020). Resolution of the Industrial District Court of Vladikavkaz of the Republic of North Ossetia-Alania dated 21April, 2020 on case N 5-76 / 2020.In Russian official legal database: Постановление Промышленного районного суда г. Владикавказа Республики Северной Осетия - Алания от 21.04.2020 по делу N 5-76/2020)

http://www.demo.garant.ru/services/arbitr/link/313594997

Russian Federal Law N 27 -FZ (2019).Федеральный закон от 18.03.2019 № 27-Ф3 (Federal Law of 18.03.2019 No. 27-FZ), http://www.consultant.ru/document/cons_doc_LAW_320399/

Russian Federal Law N 31-FZ (2019). Федеральный закон от 18.03.2019 № 31-Ф3» (Federal Law of 18.03.2019 N 31-FZ), http://www.consultant.ru/document/cons_doc_LAW_320401/

Tangcharoensathien, V., Calleja, N., Nguyen, T., Purnat, T., D’Agostino, M., Garcia-Saiso, S., ... \& Ghiga, I. (2020). Framework for managing the COVID-19 infodemic: methods and results of an online, crowdsourced WHO technical consultation. Journal of medical Internet research, 22(6), e19659. 